\title{
PELATIHAN PENGENALAN AKUNTANSI DAN PENGUATAN TATA KELOLA KOPERASI
}

\author{
Erik Nugraha $^{1}$, Henda Hendawati ${ }^{2}$, Wiwin Sukiati ${ }^{3}$, Nenny Hendajany ${ }^{4}$ \\ 1, 2,3 Progran Studi Akuntansi, Fakultas Ekonomi, Universitas Sangga Buana \\ ${ }^{4}$ Progran Studi Manajemen, Fakultas Ekonomi, Universitas Sangga Buana \\ ${ }^{1}$ korespondensi : erik.nugraha@usbypkp.ac.id
}

\begin{abstract}
ABSTRAK
Kegiatan Pengabdian Kepada Masyarakat ini dilatarbelakangi hasil survey awal pada Koperasi PKK Taruna Parahyangan, terdapat permasalan-permasalah yang diantaranya adalah : (a) Pengurus belum memiliki prosedur dan pencatatan yang sesuai dengan prinsip akuntansi berterima umum; (b) Pengurus kesulitan dalam melakukan penjualan barang-barang konsumsi yang disediakan oleh koperasi, hal ini disebabkan karena para anggota koperasi lebih senang berbelanja barang-barang konsumsi dari pihak lain. Tujuan kegiatan ini membahas mengenai teknis pencatatan dan sistem akuntansi, standar operational prosedure (SOP), azas dan prinsip untuk entitas koperasi, serta strategi dalam mengembangkan warung serba ada (waserba). Pengabdian ini menggunakan pendekatan pelatihan berupa Fokus Grup Diskusi (FGD), sedangkan sasaran pengabdian yaitu pengurus dan sebagai anggota Koperasi PKK Taruna Parahyangan yang berjumlah 30 orang. Hasil pelaksanaan pengabdian ini adalah sebagai berikut : (1) Telah dilaksanakan workshop mengenai azas dan prinsip Koperasi; (2) Telah dilaksanakan worksop mengenai strategi pengembangan Warung Serba Ada (waserba); (3) Telah dilaksanakan workhop mengenai pentingnya pembuatan prosedur dalam rangka meningkatkan tata kelola koperasi; (4) Telah dilaksanakan workshop mengenai konsep dasar akuntansi dan penyelesaian latihan kasus pencatatan akuntansi.
\end{abstract}

Kata Kunci: Pengabdian kepada Masyarakat, Koperasi, Akuntansi

\section{PENDAHULUAN}

Koperasi adalah salah satu wadah yang dapat menghimpun dana dari anggota dan menyalurkannya kembali ke anggotanya. Koperasi memiliki banyak manfaat salah satunya adalah meningkatkan kesejahteraan anggotanya. Masyarakat harus didorong untuk mau mendirikan koperasi di daerah mereka masing-masing karena Koperasi merupakan salah satu ciri khas rakyat Indonesia yang menggunakan asas kekeluargaan. Koperasi dianggap sebagai wadah yang tepat dalam menyelesaikan permasalahan ekonomi rakyat.

Kontribusi koperasi terhadap pembangunan, khususnya terhadap produk domestik bruto (PDB), masih reIatif kecil, yaitu sekitar $4 \%$. Kementerian PPN/Bappenas berencana meningkatkan peran koperasi dalam pembangunan nasional [1]. Peran koperasi dalam hal ini dapat meningkatkan inklusi keuangan atau kemudahan akses masyarakat terhadap layanan jasa keuangan, misalnya simpan pinjam. Kehadiran koperasi di sebuah komunitas masyarakat bisa menjadi jalan keluar mencari fasilitas pembiayaan yang mudah. Selain itu, pendidikan kepemimpinan penting untuk dilakukan sehingga setiap anggota belajar dan diberi kesempatan untuk mengelola koperasi. Para pengurus dan anggota koperasi juga harus dibekali kewirausahaan agar mampu mengembangkan produk dan Iayanan sesuai dengan dinamika kebutuhan.

Berdasarkan hasil survey awal pada Koperasi PKK Taruna Parahyangan, terdapat permasalan-permasalah yang diantaranya adalah : (a) Pengurus belum memiliki prosedur 
dan pencatatan yang sesuai dengan prinsip akuntansi berterima umum; (b) Pengurus kesulitan dalam melakukan penjualan barangbarang konsumsi yang disediakan oleh koperasi, hal ini disebabkan karena para anggota koperasi lebih senang berbelanja barang-barang konsumsi dari pihak lain. Berdasarkan hasil diskusi dengan pengurus koperasi, disepakati pelatihan yang berbentuk Focus Grup Diskusi untuk membantu penyelesaian permasalahan tersebut dengan tema Pelatihan Pengenalan Akuntansi Dan Penguatan Tata Kelola Koperasi.

\section{METODE}

\section{Waktu dan Tempat Pelaksanaan}

Kegiatan dilaksanakan selama 2 kali yatu pada tanggal 1 dan 8 Desember 2018, bertempat di Gedung Serba Guna Koperasi PKK Taruna Parahyangan, Jalan Taruna Raya No. 69A, Kelurahan Pasir Endah, Kecamatan Ujung Berung, Kota Bandung.

\section{Pendekatan}

Pengabdian ini menggunakan pendekatan pelatihan berupa Fokus Grup Diskusi (FGD). Pada kegiatan pelatihan, pengabdi melakukan workshop mengenai strategi pengembangan warung serba ada (waserba), pentingnya prosedur dalam tata kelola koperasi dan pencatatan sesuai dengan prinsip akuntansi berterima umum. Khusus untuk pencatatan akuntansi, diberikan soal latihan sehingga diakhir program setiap peserta dapat memahami pencatatan akuntansi dari mulai jurnal umum hingga menjadi laporan keuangan.

\section{Sasaran Pengabdian}

Sasaran pengabdian yaitu pengurus dan sebagai anggota Koperasi PKK Taruna Parahyangan yang berjumlah 30 orang.

\section{Kriteria Keberhasilan}

Kriteria keberhasilan pelatihan ini yakni banyaknya peserta yang mengikuti pelatihan (80\% dari yang diundang), meningkatnya pemahaman pengurus dan anggota koperasi mengenai pentingnya peran serta pengurus maupun anggota dalam pengembangan koperasi khususnya pengembangan warung serba ada (waserba), meningkatnya pemahaman mengenai pentingnya prosedur dalam tata kelola koperasi dan meningkatnya kemampuan para peserta untuk melakukan pencatatan akuntansi sesuai dengan prinsip akuntansi berterima umum dibuktikan dengan terselesaikannya latihan kasus yang diberikan. Untuk mengetahui efektivitas dan kebermanfaatan penyelenggaraan pengabdian dilakukan wawancara dengan beberapa peserta (terdokumentasi berupa video wawancara).

\section{HASIL DAN PEMBAHASAN}

Berdasarkan analisis situasi yang dihasilkan dari kegiatan survey awal di Koperasi PKK Taruna Parahyangan yang menyebutkan bahwa kurangnya minat anggota koperasi untuk membeli barang-barang konsumsi yang disediakan oleh koperasi, belum dituangkannya prosedur dalam bentuk dokumentasi yang baik, 
pemahaman yang masih kurang mengenai pencatatan sesuai dengan prinsip akuntansi berterima umum.

Hasil diskusi disepakati pelatihan yang akan dihadiri oleh semua pengurus Koperasi PKK Taruna Parahyangan dan sebagian anggota Koperasi PKK Taruna Parahyangan, sebagian anggota ini merupakan kaderisasi pengurus pada periode-periode yang akan datang. Kegiatan pengabdian ini diikuti oleh seluruh pengurus Koperasi yang berjumlah 15 orang dan sebagian anggota yang berjumlah 15 orang, sehingga total peserta sebanyak 30 orang.

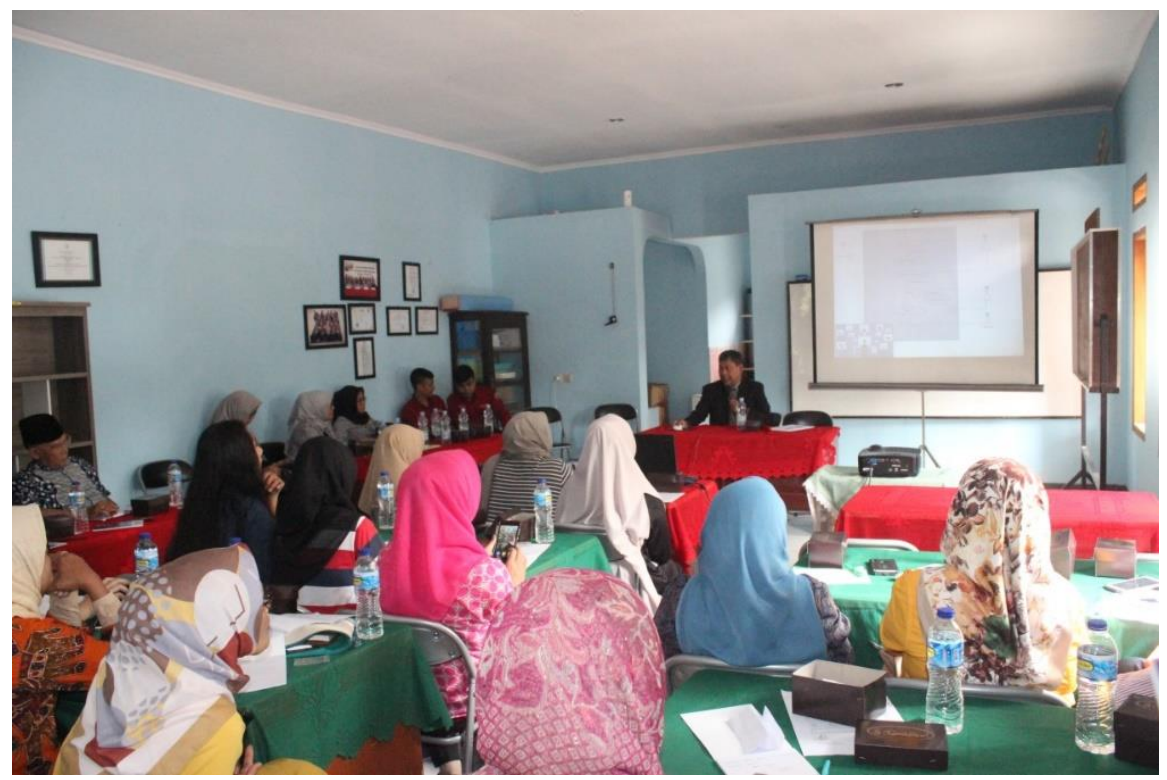

Gambar 1: Fokus Grup Diskusi Azas dan Prinsip Koperasi

Pendekatan yang dilaksanakan dalam pengabdian berupa pelatihan berbentuk Fokus Grup Diskusi (FGD), pada hari pertama pelatihan dipaparkan mengenai azas dan prinsip koperasi, hal ini dimaksudkan mengingatkan pada pengurus dan anggota agar selalu berpegang pada azas dan prinsip koperasi [2] karena fenomena yang berkembang akhir-akhir ini koperasi berubah fungsi menjadi entitas yang semata-mata mencari keuntungan dan menjadi pemilik segelintir orang dalam merauk keuntungan dengan mengatas namakan koperasi.

Selanjutnya dijelaskan bagaimana mengembangkan potensi warunga serba ada (waserba), hal ini tentunya menjadi tantangan tersendiri bagaimana memberikan keyakinan kepada para anggota agar mereka mau berbelanja barang-barang yang disediakan oleh Koperasi, dengan memberikan pemahaman jika anggota berbelanja diluar koperasi tentunya keuntungan bagi pihak lain, akan tetapi jika anggota koperasi berbelanja di Koperasi tentunya akan menjadi pendapatan bagi koperasi dan pada akhirnya akan menjadi SHU, dan SHU tersebut adalah merupakan hak anggota atau dengan kata lain, berbelanja di Koperasi akan memberikan keuntungan bagi anggota dimasa yang akan dalam bentuk Sisa Hasil Usaha yang lebih tinggi. Kemudian 
diberikan juga penjelasan barang-barang konsumsi yang disediakan, dalam kesempatan tersebut pemateri memberikan saran agar barang konsumsi yang disediakan hanya berupa Beras, Gula dan Minyak Goreng terlebih dahalu, hal ini tentunya bukan tanpa alasan, ketiga barang tersebut merupakan barang konsumsi pokok yang pastinya hampir semua orang menggunakan. Selain itu, dengan menyediakan barang konsumsi yang tepat sasaran, tentunya koperasi tidak merasakan kerugian akibat membeli berbagai jenis barang konsumsi padahal barang tersebut sebetulnya kurang diminati pembeli.

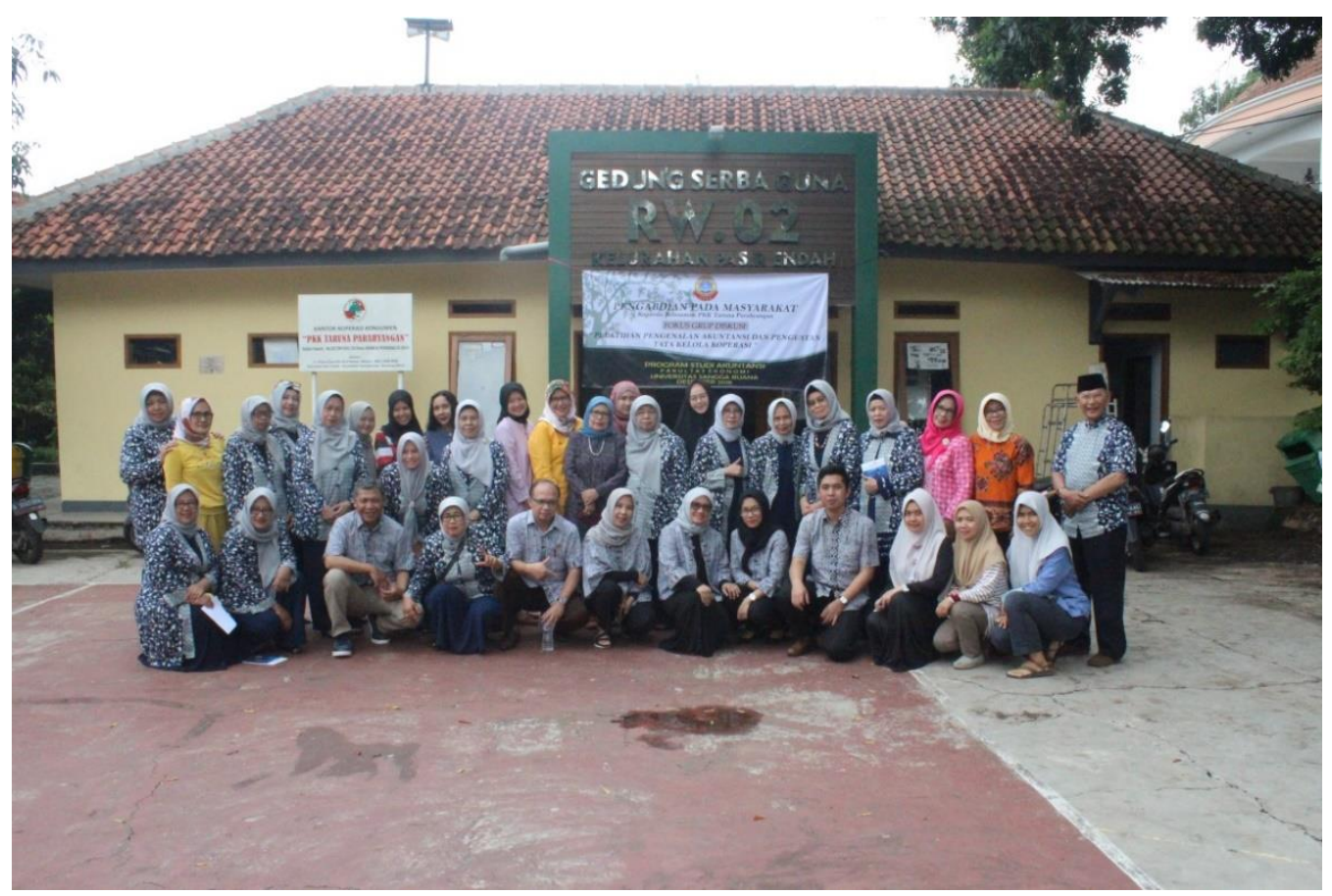

Gambar 2: Tim PKM USB YPKP dan Pengurus Koperasi PKK Taruna Parahyangan

Pada kesempatan berikutnya diberikan penjelasan mengenai pentingnya prosedur dalam rangka peningkatan tata kelola koperasi yang baik, prosedur tersebut tentunya harus tertuang dalam bentuk tulisan dan didokumentasikan dengan baik. Selain itu, diberikan juga materi dasar-dasar akuntansi dengan memberikan konsep dasar terlebih dahulu diharapkan para peserta dapat memahami esensi dalam proses pencatatan akuntansi dari mulai mencatat transaksi kedalam jurnal umum sampai menjadi laporan keuangan [3]. Pada akhir kesempatan diberikan latihan kasus pencatatan akuntansi dan dilakukan pembahasan secara bersamabersama.

Secara garis besar, hasil pelaksanaan pengabdian ini adalah sebagai berikut :

1. Telah dilaksanakan workshop mengenai azas dan prinsip Koperasi.

2. Telah dilaksanakan worksop mengenai strategi pengembangan Warung Serba Ada (waserba).

3. Telah dilaksanakan workhop mengenai pentingnya pembuatan prosedur dalam rangka meningkatkan tata kelola koperasi. 
4. Telah dilaksanakan workshop mengenai konsep dasar akuntansi dan penyelesaian latihan kasus pencatatan akuntansi.

\section{Kendala dan Pemecahannya}

Pelaksanaan pengabdian kepada masyarakat dengan tema Pelatihan Pengenalan Akuntansi Dan Penguatan Tata Kelola Koperasi di Koperasi PKK Taruna Parahyangan telah terlaksana dengan baik. Meskipun demikian, pada pelaksanaan tersebut bukan berarti tidak menemui berbagai hambatan. Salah satu hambatan yang ditemui pada kegiatan workshop adalah kekurangpercayadirian para peserta workshop dalam menyelesaikan latihan kasus pencatatan akuntansi. Mereka masih merasa kurang percaya diri dalam mengerjakan dan menyelesaikan kasus latihan tersebut meskipun didampingi langsung oleh fasilitator. Untuk mengatasi permasalahan tersebut harus dilakukan pendampingan secara terus menerus dan dilaksanakan dengan semaksimal mungkin.

\section{KESIMPULAN DAN SARAN}

\section{Kesimpulan}

Berdasarkan kegiatan pengabdian yang telah dilaksanakan dapay disimpulkan pengabdian berupa pelatihan berbentuk Fokus Grup Diskusi (FGD) telah terlaksana sesuai dengan jadwal dan kriteria keberhasilan dengan hasil pelaksanaan pengabdian ini adalah sebagai berikut :
1. Telah dilaksanakan workshop mengenai azas dan prinsip Koperasi.

2. Telah dilaksanakan worksop mengenai strategi pengembangan Warung Serba Ada (waserba).

3. Telah dilaksanakan workhop mengenai pentingnya pembuatan prosedur dalam rangka meningkatkan tata kelola koperasi.

4. Telah dilaksanakan workshop mengenai konsep dasar akuntansi dan penyelesaian latihan kasus pencatatan akuntansi.

\section{Saran}

Saran yang diajukan berdasarkan hasil pelaksanaan kegiatan pengabdian yaitu hendaknya dilaksanakan kegiatan lanjutan sebagai tindak lanjut atas kegiatan pengabdian yang telah dilaksanakan, berupa pendampingan pelaksanaan penelitian.

\section{DAFTAR PUSTAKA}

[1] Finance.Detik.com. (2018). RI Punya 150.000 Koperasi, Kontribusi ke Ekonomi Hanya 4\%. Diperoleh 23 November 2018, dari https://finance.detik.com/moneter/d3580648/ri-punya-150000-koperasikontribusi-ke-ekonomi-hanya-4

[2] Indonesia (2016). Undang-Undang Republik Indonesia Nomor 25 Tahun 1992 Tentang Perkoprasian. Jakarta : Menteri Sekertaris Negara Republik Indonesia.

[3] Weygandt., Kimeel., Kieso. (2015). Accounting Principles. Twelfth Edition. John Wiley \& Sons 